\title{
An Examination of Swedish Human Resource Management Students' Beliefs about What Work Should Ideally Be Like
}

\author{
Gunne Grankvist ${ }^{1}$ \\ ${ }^{1}$ Department of Social and Behavioural Studies, University West, Sweden \\ Correspondence: Gunne Grankvist, Department of Social and Behavioural Studies, University West SE 46686 \\ Trollhattan, Sweden.
}

Received: May 4, 2015

Accepted: May 19, 2015

Available online: June 29, 2015

doi:10.11114/ijsss.v3i4.917

URL: http://dx.doi.org/10.11114/ijsss.v3i4.917

\begin{abstract}
Human Resource Management students' beliefs about how work should be organised will influence their behaviour in future professional positions. This prompted a study in which students in a three-year programme in Human Resource Management at University West in Sweden commented on a number of statements about what work should ideally be like. All 140 respondents were born between 1978 and 1990 and hence belong to Generation Y, also known as Generation Me. The respondents generally agreed strongly with humanistic beliefs about work and female students agreed with humanistic beliefs to a far greater extent than male students.
\end{abstract}

Keywords: Beliefs about work, Generation Y, Human Resource Management students, Sweden

\section{Introduction}

Contradictory beliefs about what work should be like and the characteristics of an actual job have been found to be associated with negative attitudes towards work and a lower job satisfaction. For example, Irving and Montes (2009), in a Canadian sample, found that unmet expectations of a job were significantly associated with lower job satisfaction. In an international meta-analysis of 31 studies, with a total of 17241 respondents, it was reported that unmet job expectations were strongly associated with lower levels of job satisfaction and organisational commitment (Wanous, Poland, Premack, \& Davis, 1992). Employees' beliefs about how work should be organised and how changes should be implemented have also been shown to be related to how successful an organisation is in achieving desired results, (e.g., Beer, Eisenstat, \& Spector, 1990; Madsen, Miller, \& John, 2005; Todnem By, 2007).

On the basis of a literature search, Buchholz (1978) identified five belief systems about what work is, or should be, like. These belief systems are philosophies, assumptions, or views about the role work has, can be expected to have, and should have in people's lives. One of these, the humanistic belief system, is the view or belief that work should not only be an instrument to fulfil basic material needs and wants; work should also allow employees to discover their potential as human beings, to reach higher stages of human development, and enable them to realise their potentials. What happens to human beings in the workplace is just as, or even more, important than the output of the work process. As a consequence, work should be designed, or redesigned, to be more meaningful and fulfilling. "The job should be a source of new experiences" and "Work can be organised to allow for human fulfilment" (Buchholz, 1978, p. 222) are examples of items used to measure the extent of humanistic work-related beliefs.

Since beliefs about work, attitudes toward work, and work values are central concepts in this paper, it should be mentioned that values are usually defined as rather abstract goals and preferred end-states for which we strive. One of the most influential definitions of the value construct has been provided by Rokeach (1973): "A value is an enduring belief that a specific mode of conduct or end-state of existence is personally or socially preferable to an opposite or converse mode of conduct or end-state of existence" (p. 5). Values are hence preferred end-states for which we strive, while beliefs are more concrete assumptions about the world. A web of beliefs constitutes a system of information to which we can refer for answers. As such, belief systems work as response models in which we can find ways to understand our reality. We can, and sometimes do, question our beliefs, but more basic beliefs are rarely questioned or altered (Eagly \& Chaiken, 1993; Rokeach, 1973). Attitudes are affective responses to our views of reality. Our values, and more directly our beliefs, shape our attitudinal responses (Eagly \& Chaiken, 1993).

In a paper on both fundamental and work values, Ros, Schwartz, and Surkiss (1999) discussed an intrinsic work value, 
which expressed autonomy, interest in human development, and creativity at work. Importance attached to the item "interesting and varied work" (p. 59) was used as a measure of importance attached to such an intrinsic work value. In line with the arguments presented by Ros et al. (1999), it is reasonable to classify humanistic beliefs in the Buchholz model as closely related to this intrinsic work value.

\subsection{Gender Differences}

Possible gender differences in intrinsic work values and beliefs about work have been in focus in a number of studies. It was, for example, suggested in the early 1970s that women in the USA were more committed to humanistic beliefs about work than men. Cultural stereotyping that emphasised the importance of human and social, rather than technical, skills for women was presented as an argument (Mitchell, 1972). However, in a survey conducted in the USA of 340 blue-collar and white-collar works, 72 union leaders and 366 senior managers, no support was found for this suggestion (Buchholz, 1978). A study of over 250 adults in the UK in the 1980s found no significant difference between women and men in the importance attached to humanistic beliefs about work. There was, however, a positive correlation between holding humanistic beliefs and a desire to have a job that demanded a high degree of involvement (Furnham, 1984). A Russian study of 292 managers found that female managers were more committed than male managers to the humanistic beliefs presented by Buchholz (Puffer, McCarthy, \& Naumov, 1997). A longitudinal study in the USA with participants from the 1976 to 1980 cohorts - a total of 2,373 respondents ranging in age from about 22 to 32 - found that young women attached greater importance than men to intrinsic job rewards. Examples of such intrinsic rewards are that work should have the potential for learning and provide opportunities to be creative (Johnson, 2001). In a similar vein, a study of the job values held by US high school seniors, conducted from 1976 to 1991, found that young women attached greater importance to intrinsic rewards (Marini, Fan, Finley, \& Beutel, 1996). A longitudinal study of the work values held by engineering and nursing students was conducted in Sweden in the 1990s. The study began in 1993, and included 353 female and 31 male students. In total 173 male and 48 female engineers participated from 1995 onwards. Three measurement occasions covered about four and half years from the end of these students' vocational education. The study included the work value of "self-realisation", which focused on carrying out one's work wholeheartedly, being able to use imagination and creativity, and having a sense of achievement (e.g., developing one's personality). No statistically significant differences between men and women were found in the initial measurements, nor were significant differences found over time in the degree of importance attached to this value (Hagström \& Kjellberg, 2007).

\subsection{Generation $Y$}

Today's younger workforce, born roughly between 1978 and 2000, have been labelled Generation Y, generation Me, or the Millennials (Kehrli \& Sopp, 2006; Twenge, 2006). Anecdotal evidence highlights that this generation has been characterised by high expectations of themselves and employers. Individuals in this generation expect fairness and transparency in communication with managers, who are expected to be engaged in their professional development. They seek continuous learning, development, and challenges. They like to be responsible, to make a difference, and they are goal-orientated (Gravett \& Throckmorton, 2007; Tulgan, 2009). Research on Generation Y has shown higher levels of self-esteem, but also higher levels of narcissism, anxiety, and depression, compared to previous generations (Twenge \& Campbell, 2008). Furthermore, Generation Y has been found to hold high expectations when it comes to salary growth, promotional opportunities (Ng, Schweitzer, \& Lyons, 2010), and involvement in organisational decision-making. In a study of young people in Australia, soon to enter the work force, Lindorff (2010) found that happiness, work success, and friendship were highly important values. Life and work activities that contributed to society were, however, rated as relatively unimportant. Kupperschmidt (2000) argued that an understanding of the differences between generations can be a tool for managers to achieve greater productivity, more innovation, and higher levels of corporate citizenship. It has been argued that organisations today are employing the most educated workforce in the history of the world (Burke \& $\mathrm{Ng}, 2006$ ). To be able to compete for these young and ambitious workers, employers need to understand and meet their demands. Studies of young people's expectations and beliefs about what work should be like are consequently of interest.

Based on previous research (Buchholz, 1978; Gravett \& Throckmorton, 2007; Lindorff, 2010; Ng, Schweitzer, \& Lyons, 2010; Ros, Schwartz, \& Surkiss 1999; Tulgan, 2009) it is highly reasonable to view humanistic beliefs about work as relatively parallel to core views among individuals in Generation Y. I therefore propose that individuals in this generation will generally show high levels of humanistic beliefs. Results presented above suggest that if there is a gender difference, women are more likely to hold strong humanistic work-related beliefs (Johnson, 2001; Marini et al., 1996; Puffer et al., 1997). Human Resource Management (HRM) students are an interesting group since they are likely to work with organisational issues in in their future professional roles. Their beliefs about how work should (ideally) be organised will influence how they, for example, contribute to implementing changes and deal with conflicts arising from such changes. This prompted a study with Generation Y HRM students, focusing on their beliefs about work. 


\subsection{Hypothesis}

1. Generation Y HRM students will generally agree strongly with humanistic beliefs about work.

2. Female Generation Y HRM students will agree with humanistic beliefs about work at least as strongly as, or more strongly than, male respondents from the same population.

\section{Method}

\subsection{Participants}

A total of 140 students in the three-year HRM programme (six semesters with 30 ECTS credits in each semester) at University West in Sweden participated on a voluntary basis. All data was collected in 2010.

\subsection{Design and Procedure}

A paper-and-pencil questionnaire was used to collect data. The questionnaire included statements about what work should be like, the number of university credits held by respondents, years of work experience, years of work experience in a managerial position, age and gender.

Before data collection all participants were informed that confidentiality was guaranteed and that the results would be presented at group level only. In accordance with the requirement for consent, I informed the participants that their participation was strictly voluntary.

\subsection{A Measure of Humanistic Beliefs about Work}

Three of the ten humanistic belief statements presented by Buchholz (1978) were used. This selection was based on my assessment of which of the statements in a questionnaire that is more than 40 years old would work in a contemporary Swedish context.

(1) One's job should give one a chance to try out new ideas.

(2) Work should enable one to learn new things.

(3) The job should be a source of new experiences.

Ratings were given on a five-point Likert scale with endpoints defined as (1) strongly disagree and (5) strongly agree. Since these statements leaned towards self-realisation, I named them Humanistic Self-Realisation Work Beliefs (HWB).

\section{Results}

All respondents were born between 1978 and 2000 and hence belonged to Generation Y. Of the 140 respondents, 112 were women and 28 were men. This $80 / 20 \%$ ratio of women to men is common in HRM programmes in Sweden. At the time of data collection in 2010, they were aged between 20 and 32, and their mean age was $23.56(\mathrm{SD}=2.95)$. One semester of full-time study is equivalent to 30 ECTS credits. The respondents' mean number of credits was 59 , ranging from 0 to 230. Total work experience was on average 4.51 years $(S D=2.94)$, ranging from 0 to 15 years. Mean experience of working in a managerial position was 0.42 years $(S D=0.91)$, ranging from 0 to 4 years.

Cronbach's alpha (Cohen, 2013) across the three items used to measure the degree of HWB was 0.63. Inter-item correlations ranged between 0.33 and 0.41 , while corrected item-total correlations ranged between 0.41 and 0.48 . This relatively high internal consistency (Cohen, 2013) justified the calculation of a mean across these items as a measure of the extent of overall HWB.

\subsection{Generation $Y$}

The mean for this HWB variable was 4.45 ( $\mathrm{SD}=0.43$ ). An overwhelming majority $(88 \%)$ of the respondents indicated (as an average across the three items) 4 or more on the scale with endpoints (1) strongly disagree and (5) strongly agree. About half of the respondents (51\%) indicated 4.5 or more on the same scale. These results are in line with the first hypothesis.

\subsection{Gender Aspects}

The mean value for women was $4.49(\mathrm{SD}=0.41)$ and for men $4.30(\mathrm{SD}=0.48), \mathrm{t}(138)=2.21, \mathrm{p}=0.03$. As a measure of the size of this gender-based difference, Cohen's d (Cohen, 2013) was calculated to be 0.45 . A rule of thumb, put forward by Cohen, suggests that a small, medium, and large difference or, to use Cohen's term, "effect size", equals $0.20,0.50$ and 0.80 , respectively.

As can be seen in table 1, the strength of an individual's agreement with HWB was not statistically significantly correlated with age, amount of work experience, work experience in a managerial position, or number of ECTS credits held. 
Table 1. Correlations with Humanistic Self-Realisation Work Beliefs (HWB)

\begin{tabular}{ll}
\hline Measures & \\
\hline Age & .02 \\
Work experience & .06 \\
Work experience in managerial positions & .07 \\
Number of ECTS credits & -.10 \\
\hline
\end{tabular}

Note: No correlations were statistically significant at the $5 \%$ level

In a linear regression analysis, gender, age, work experience, work experience in a managerial position, and ECTS credits were used as predictors of how strongly HWB were held. As can be seen in table 2, only gender was found to be a statistically significant predictor. A positive value indicated that women held HWB more strongly than men.

Table 2. Linear Regression Analysis For HWB Regressed On Gender, Age, Work Experience, Work Experience In A Managerial Position, And Number Of ECTS Credits.

\begin{tabular}{llcc}
\hline Measures & B & SE B & B \\
\hline Gender & .27 & .08 & $.27^{*}$ \\
Age & .00 & .02 & .02 \\
Work experience & .00 & .02 & .03 \\
Work experience in managerial positions & .05 & .04 & .10 \\
Number of ECTS credits & .00 & .00 & -.11 \\
\hline
\end{tabular}

Note: ${ }^{*} \mathrm{p}<.05 . \mathrm{F}(5,133)=2.83, \mathrm{p}<.05 . \mathrm{R}_{\text {adj }}^{2} .06$

In line with the second hypothesis, these results show that the female respondents on average agreed with HWB more strongly than the male respondents.

\section{Discussion}

The results of this study showed that Swedish HRM students who belonged to Generation Y strongly agreed with HWB. Furthermore, I found that female students agree more strongly with these beliefs than male students. However, no comparisons with other generations were made and it is not possible to know the extent of any generational difference. If, however, such generational differences do exist (in Sweden), and those in Generation Y agree more strongly with HWB about how work should be organised, this is something that employers should be aware of. In order to remain competitive and be capable of making necessary changes, companies need to find ways of using the specific qualities and strengths that different generations possess (Burke \& $\mathrm{Ng}$, 2006). A good fit between beliefs and expectations about what work should be like and the characteristics of an actual job held by an employee also plays a key role in job satisfaction (Irving \& Montes, 2009; Wanous et al., 1992).

A clear and substantive result from the present study is that Swedish female HRM students agreed more strongly with HWB than male students. This is a result that employers and companies should be aware of and use in a constructive way. These young women's high expectations of finding a job that allows for continuous learning and personal development should be viewed as a positive force. These newcomers in the HRM arena want to make a difference, to be innovative, to participate in organisational decision-making, and to realise their potential as human beings, while being involved in their job.

Although results presented in this study are based on a limited sample, they can be used for comparisons with other groups of students and employers, managers, and other employees. If beliefs about how work should be organised differ substantially between groups that are expected to interact, there is potential for conflict and problems with implementing organisational changes.

An interesting question is whether these HRM students' HWB will change when they start work. Results presented by Hagström and Kjellberg (2007) indicate that work values, such as those in the present study, are fairly stable and not likely to change, at least not in the short term (among engineers and nurses). It is, however, undoubtedly the case that not all students will find jobs that meet their needs. Furthermore, if they do not manage to subsequently find a more rewarding job, it is possible that changes will occur in their work values and beliefs about what work should be like, in a way that 
they can preserve a positive self-concept and avoid experiencing low job satisfaction. Viewing previous work aspirations as unrealistic and increasing the importance of those rewards and values that the individual has managed to attain could be a successful strategy for strengthening self-esteem.

\section{Conclusions}

Organisations today arguably employ the most educated workforce ever. To be able to compete for these young and ambitious workers, it is necessary to understand their demands. Knowledge about their beliefs about what work should ideally be like contributes to a better understanding of their demands and hopes. This study showed that Swedish HRM students strongly agreed with humanistic self-realisation beliefs about work. It was also found that female students agreed more strongly with these beliefs than male students.

\section{Acknowledgements}

This research was funded by University West (www.hv.se). I thank all the participants who voluntarily and without compensation answered the survey questions.

\section{References}

Beer, M., Eisenstat, R. A., \& Spector, B. (1990). Why change programs don't produce change. Harvard Business Review, November-December.

Buchholz, R. A. (1978). An empirical study of contemporary beliefs about work in American society. Journal of applied psychology, 63(2), 219. http://dx.doi.org/10.1037/0021-9010.63.2.219

Burke, R. J., \& Ng, E. (2006). The changing nature of work and organizations: Implications for human resource management. Human Resource Management Review, 16(2), 86-94. http://dx.doi.org/10.1016/j.hrmr.2006.03.006

Cohen, J. (2013). Statistical power analysis for the behavioral sciences: Routledge Academic.

Eagly, A. H., \& Chaiken, S. (1993). The psychology of attitudes: Harcourt Brace Jovanovich College Publishers.

Furnham, A. (1984). Work values and beliefs in Britain. Journal of Organizational Behavior, 5(4), 281-291. http://dx.doi.org/10.1002/job.4030050405

Gravett, L., \& Throckmorton, R. (2007). Bridging the generation gap: How to get radio babies, boomers, Gen Xers, and Gen Yers to work together and achieve more: Career Press.

Hagström, T., \& Kjellberg, A. (2007). Stability and change in work values among male and female nurses and engineers. Scandinavian Journal of Psychology, 48(2), 143-151. http://dx.doi.org/10.1111/j.1467-9450.2007.00576.x

Irving, P. G., \& Montes, S. D. (2009). Met expectations: The effects of expected and delivered inducements on employee satisfaction. Journal of Occupational and Organizational Psychology, 82(2), 431-451. http://dx.doi.org/10.1348/096317908X312650

Johnson, M. K. (2001). Job values in the young adult transition: Change and stability with age. Social Psychology Quarterly, 297-317. http://www.jstor.org/stable/3090156

Kehrli, S., \& Sopp, T. (2006). Managing generation Y. HRMagazine, 51(5), 113.

Kupperschmidt, B. R. (2000). Multigeneration employees: strategies for effective management. The health care manager, 19(1), 65-

Lindorff, M. (2010). The personal values of tomorrow's workforce: Similarities and differences across sex and nationality. Journal of Management and Organization, 16(3), 353. http://dx.doi.org/10.1017/S18333672000017

Madsen, S. R., Miller, D., \& John, C. R. (2005). Readiness for organizational change: do organizational commitment and social relationships in the workplace make a difference? Human Resource Development Quarterly, 16(2), 213-234. http://dx.doi.org/10.1002/hrdq.1134

Marini, M. M., Fan, P.-L., Finley, E., \& Beutel, A. M. (1996). Gender and job values. Sociology of Education, 49-65. http://dx.doi.org/10.2307/2112723

Mitchell, J. (1972). The situation of women. The capitalist system. Englewood-Cliffs, N.J.: Prentice-Hall.

Ng, E. S., Schweitzer, L., \& Lyons, S. T. (2010). New generation, great expectations: A field study of the millennial generation. Journal of Business and Psychology, 25(2), 281-292. http://dx.doi.org/10.1007/s10869-010-9159-4

Puffer, S. M., McCarthy, D. J., \& Naumov, A. I. (1997). Russian managers' beliefs about work: Beyond the stereotypes. Journal of World Business, 32(3), 258-276. http://dx.doi.org/10.1016/S1090-9516(97)90011-0

Rokeach, M. (1973). The nature of human values: Free press. 
Ros, M., Schwartz, S. H., \& Surkiss, S. (1999). Basic individual values, work values, and the meaning of work. Applied psychology, 48(1), 49-71. http://dx.doi.org/10.1080/026999499377664

Todnem-By, R. (2007). Ready or not.... Journal of Change Management, 7(1), 3-11. http://dx.doi.org/10.1080/14697010701265249

Tulgan, B. (2009). Not everyone gets a trophy: How to manage generation Y: John Wiley \& Sons.

Twenge, J. M. (2006). Generation me: Why today's young Americans are more confident, assertive, entitled--and more miserable than ever before: Simon and Schuster.

Twenge, J. M., \& Campbell, S. M. (2008). Generational differences in psychological traits and their impact on the workplace. Journal of Managerial Psychology, 23(8), 862-877. http://dx.doi.org/10.1108/02683940810904367

Wanous, J. P., Poland, T. D., Premack, S. L., \& Davis, K. S. (1992). The effects of met expectations on newcomer attitudes and behaviors: a review and meta-analysis. Journal of applied psychology, 77(3), 288. http://psycnet.apa.org/doi/10.1037/0021-9010.77.3.288

\section{(cc) $\mathrm{BY}$}

This work is licensed under a Creative Commons Attribution 3.0 License. 